\title{
Ankara ilinde eğitim alan aile hekimliği asistanlarının değerlendirilmesi gereksinimlerinin
}

Evaluation of training needs of family medicine residents educated in Ankara

\author{
Hülya Yıkılkan*, Özlem Türedi, Cenk Aypak, Süleyman Görpelioğlu
}

Aile Hekimliği Kliniği (Dr. H. Yıkılkan, Dr. Ö. Türedi, Dr. C. Aypak, Prof. Dr. Süleyman Görpelioğlu), Dışkapı Yıldırım Beyazıt Eğitim ve Araştırma Hastanesi, TR-06110 Ankara

\section{Özet}

Amaç. Özellikle yetişkinler için bir eğitim müfredatı hazırlamanın ilk adımı eğitim ihtiyaçlarının ne olduğunun tespit edilmesidir. Bu çalışmanın amacı, Ankara ilinde eğitim alan Aile hekimliği asistanlarının temel yeterlilikler açısından eğitim ihtiyaçlarını, kendi değerlendirmelerinden yola çıkarak ortaya koymak ve standardize bir müfredat programı oluşturulmasına katkıda bulunmaktır. Yöntem. Bu kesitsel çalışmanın evrenini 01 Mart-01 Haziran 2012 tarihleri arasında Ankara ilinde; tıp fakültesi ve eğitim araştırma hastanelerinde aile hekimliği asistanlığı yapmakta olanlar oluşturmuştur. Çalışma yürütücüleri tarafindan oluşturulan anket formu, çalışmaya katılmayı kabul edenlere uygulanmıştır. Bulgular. Ankara ilinde halen aile hekimliği asistanlığı yapmakta olan 120 asistanın 77'sine $(\% 64,1)$ ulaşıldı. Uzmanlık sonrası planlarına bakıldığında, \%42,9'u saha hekimi, \%40,3'ü akademisyen, \%7,8'i özel, \%1,3'ü tıp dışı bir alanda çalışmayı planlarken; \%7,8'i ise kararsızdı. Aile hekimliği temel uygulamaları ve katılımcıların yeterlilikleri kendileri tarafından değerlendirildiğinde; ölmekte olan hasta bakımı, ergen sağlığı ve danışmanlığı, temel yenidoğan bakımı, madde bağımlılığı, istismar ve şiddet, çevre kaynaklı hastalıklar ve meslek hastalıkları, evde bakım, yaşam ve ölümle ilgili konularda uygulama yapma imkanlarının az olduğu görüldü. Katılımcılara uygulanan 'en iyi nasıl öğrenirim' anketi sonuçlarına göre, tercih ettikleri en iyi öğrenme yöntemleri sırası ile işitsel (n: 40), kinetik (n: 28), okuyarak (n: 28) ve görseldi (n: 12). Sonuç. Aile Hekimliği Uzmanlık Eğitimi hastane rotasyonları, birinci basamak uygulama eğitimi ve eğitsel etkinliklerden oluşmaktadır. Katılımcıların, hastane rotasyonlarında uygulama imkanlarının daha seyrek olduğunu belirttikleri konuların, birinci basamak uygulama eğitimi ve eğitsel etkinliklere dahil edilmesi uygun olacaktır. Katılımcıların \%40,3'ü, özellikle de 2006 yılı ve sonrası mezun olanlar daha sıklıkla akademisyen olmayı planlamaktadır (p: 0,01). Ancak akademisyenliğin en temel özelliklerinden biri olan güncel bilgileri takip etmek için makale okuma durumlarına bakıldığında, katılımcılar yeterli sıklıkta Türkçe ve İngilizce makale okumadıklarını belirtmektedirler. Çalışmamıza göre katılımcıların en çok tercih ettikleri öğrenme metodu işitseldir ancak bir eğitim programında birden çok yöntemin bir arada kullanılmasının öğrenmenin kalıcılığını artırdığı bilinmektedir.

Anahtar sözcükler: Aile Hekimliği, uzmanlık eğitimi, yeterlikler, öğrenme gereksinimi

\begin{abstract}
Aim. Especially for adults, the first step in the development of a training curriculum is to determine the training needs. The aim of this study is to evaluate the training needs according to core competencies by the opinions of Family medicine residents that are educated in Ankara and to contribute to creation of a standardized training curriculum. Method. Residents educated in Family medicine departments of Universities and Training and Research Hospitals in Ankara between March 01 and June 01, 2012 were the universe of this cross-sectional study. The questionnaire formed by the investigators was applied to those who accepted. Results. Seventy seven $(64.1 \%)$ residents of a total of 120 were reached. Post-residency working decisions of the residents were field practice by $42.9 \%$, academic plans by $40.3 \%$, private practice by $7.8 \%$, working non-medical by $1.3 \%$ and uncertain by $7.8 \%$. According to self-evaluations of residents about practice and competencies, they had less opportunity to practice about the issues like: dying patient care, adolescent health and counseling, basic newborn care, substance abuse, abuse and violence, environment related illnesses and occupational diseases, home care, life and death issues. According to 'How do I learn best?' survey results, preferred methods were auditory (n: 40), kinesthetic (n: 28), reading (n: 28) and visual (n: 12) respectively. Conclusion. Family medicine
\end{abstract}


specialty training consists of hospital rotations, primary care practice training and educational activities. The issues that were mentioned by the residents as less practiced, should be included into the educational activities and primary care practice training. $40.3 \%$ of the residents, especially graduated at or after the year 2006, were planning to be academics (p: 0.01). One of the basic features of being an academic is reading scientific papers to follow up-to date information, but residents stated that they were not reading Turkish and English papers with sufficient frequency. Most preferred learning style was auditory, but it is known that using more than one method in educational programmes will improve consistency of learning.

Keywords: Family Medicine, specialty training, competencies, learning needs

Geliş tarihi/Received: 03 Kasım 2012; Kabul tarihi/Accepted: 24 Ocak 2013

*İletişim adresi:

Dr. Hülya Yıkılkan, Aile Hekimliği Kliniği, Dışkapı Yıldırım Beyazıt Eğitim ve Araştırma Hastanesi, TR-06110 Ankara. E-posta: hulyayikilkan@hotmail.com

\section{Giriş}

Aile Hekimliği, kendine özgü eğitim içeriği, araştırması, kanıt temeli ve klinik uygulaması olan akademik ve bilimsel bir disiplin ve birinci basamak yönelimli klinik bir uzmanlıktır [1]. Birinci basamak yönelimli olması nedeniyle geniş bir biyopsikososyal yelpazede karar verme süreçlerini içerir. Bunun sonucunda aile hekimlerinin bütün klinik branşlara ilgi duyması, ancak bu branşların birinci basamağa yansıyan uygulamaları konusunda, daha fazla uzmanlaşmaları ve yenilikleri takip etmeleri gerekir. Ülkemizin birinci basamak sağlı hizmetlerinin istenen düzeyde yürütülebilmesi için ihtiyaç duyulan sayı ve kalitede aile hekimliği uzmanı yetiştirilmesi ancak uzmanlık eğitiminin standardize edilmesi ve birinci basamak hizmetlerinin bakış açısı ile düzenlenmesiyle mümkündür [2].

Klinik yeterliliğin arttırılması asistan eğitiminde bir hedeftir. Uzmanlık eğitim programı, hekimin uzmanlık eğitimini tamamladıktan sonra çalışacağı alanla ilgili olarak hekimlik bilgi ve becerilerini artıracak, tutum ve davranışlarını geliştirecek şekilde planlanmalıdır. Aile hekimliği asistanları için birinci basamaktaki görevlerini ideal şekilde yerine getirmelerini sağlayacak bir müfredat programının geliştirilmesi önemlidir.

Asistan eğitimi pek çok yönüyle tıp fakültesi öğrencilerinin eğitiminden farklılık gösterir. Öğrenme süreci öncesinde edinilmiş kişisel bilgi, görüş, inanç, tutum ve amaçlar öğrenmeyi etkilemektedir [3]. Asistanların henüz tıp fakültesinden mezun olmamış öğrencilere göre önceki çalışma dönemlerinden taşıdıkları daha yoğun deneyimleri vardır ve ancak öğrendiklerini içselleştirebildikleri sürece kendilerini geliştirebilirler. $\mathrm{Bu}$ nedenle, her asistanın kişisel öğrenme gereksinimlerinin ortaya çıkarılması ve bu gereksinimleri nasıl karşılayacağının öğretilmesi ön planda olmalıdır.

Müfredat geliştirmede ilk aşama iş analizi ve genel gereksinimlerin belirlenmesidir. $\mathrm{Bu}$ aşama, işi ideal olarak yapabilmek için bilinmesi, önemsenmesi ve becerilmesi gereken tüm özelliklerin sıralanmasıdır. WONCA (World Organization of National Colleges, Academies and Academic Associations of General Practitioners/Family Physicians), WONCA Avrupa 2002 toplantısında aile hekimliği/genel pratisyenlikle ilgili çekirdek yeterlikleri tanımlamıştır [1]. Bu altı çekirdek yeterlik: 1. Birinci basamak yönetimi 2. Kişi merkezli bakım 3. Özgün problem çözme becerileri 4. Kapsamlı yaklaşım 5. Toplum yönelimli olma 6. Bütüncül yaklaşım-modellemedir. Aynı şekilde Dünya Sağlı Örgütü (DSÖ) de yayınladığı bildirgede 21. yüzyılın 5 yıldızlı hekimlerini; hastanın tüm sağlık ihtiyaçlarını karşılayan (care provider), optimal sağlık teknolojisinin kullanımına karar verebilen (decision maker), sağlıklı yaşam tarzını destekleyen (communicator), hasta ve toplumun ihtiyaçlarını dengeleyebilen (community leader) ve takım içinde ortak çalışan (manager) şeklinde tanımlamıştır [4]. Aile hekimliği asistanlarının, tanımlanmış olan yeterliklerle donanmış olarak uzman olmaları gerekmektedir. 
Müfredat geliştirmede ikinci adım, aile hekimliği asistanlarının eğitim gereksinimi olan alanların belirlenmesidir. Çalışmamızın amacı, aile hekimliği asistanlarının temel yeterlilikler açısından eğitim ihtiyaçlarını, kendi değerlendirmelerinden yola çıkarak ortaya koymak ve standardize bir müfredat programı oluşturulmasına katkıda bulunmaktır. Ayrıca, asistanların baskın öğrenme biçimleri değerlendirilerek, müfredat programında kullanılabilecek eğitim yöntemlerini önermek amaçlanmıştır.

\section{Gereç ve yöntem}

Çalışmaya 01 Mart-01 Haziran 2012 tarihleri arasında Ankara ilinde; tıp fakültesi ve eğitim araştırma hastanelerinde, çalışmanın yürütüldüğü tarihler arasında halen aile hekimliği asistanlığı yapmakta olanlar dahil edilmiştir. Kesitsel tipte bir araştırmadır. Çalışmada, örneklem seçilmemiş olup, evrenin tümüne yani aile hekimliği asistanlığ yapmakta olan 120 kişiye ulaşmak hedeflenmiştir. Çalışma yürütücüleri tarafından oluşturulan anket formu, çalışmaya katılmayı kabul edenlere uygulanmıştır. Anket formu, 3 bölümden oluşmaktadır. Birinci bölüm, katılımcıların demografik özellikleri, uzmanlık sonrası planları, aile hekimliği alanında kendilerini geliştirmek için kullandıkları yöntemleri, araştırma ve akademik çalışmaları sorgulamakta; 2 . bölüm sağlık hizmeti verilen özel gruplar ve konularda ve çeşitli semptomlarda uygulama ve kendilerince yeterliklerini değerlendirmekte; 3. bölüm ise 'en iyi nasıl öğrenirim' anketinden oluşmaktadır [5]. İkinci bölümde, Aile hekimliği temel uygulamalarında katılımcıların yeterlikleri sorgulanırken, 1 (zayıf) ve 5 (yeterli) arasında değişen 5'li likert tipi ölçek kullanılmıştır. Son bölümdeki ‘en iyi nasıl öğrenirim' anketi kendine özgü değerlendirme formu ile skorlanmış ve sonuç olarak katılımcının okuyarak, görsel, kinetik veya işitsel yöntemle daha iyi öğrendiği belirlenmiştir. Skorları eşit olan birden fazla yöntem olması durumunda, en fazla skoru alan yöntemler en iyi öğrenme yöntemi değerlendirilmesine eklenmiştir.

İstatistiksel değerlendirmede sonuçlar ortalama \pm standart sapma ya da sayı (\%) olarak ifade edilmiştir. Gruplar arası karşılaştırmalarda, normal dağılım gösteren değişkenler için bağımsız gruplarda $t$ testi, normal dağılım göstermeyen değişkenler için MannWhitney U testi kullanılmıştır. Kategorik verilerin gruplar arası karşılaştırmasında ki-kare ve Fisher'in kesin ki-kare testleri kullanılmıştır. İstatistiksel analizler SPSS 18.0 programı kullanılarak yapılmış, istatistiksel anlamlılık sınııı $\mathrm{p}<0,05$ değeri olarak kabul edilmiştir.

\section{Bulgular}

Çalışmanın yürütüldüğü tarihler arasında Ankara ilinde halen aile hekimliği asistanlığı yapmakta olan 120 asistanın 77'sine $(\% 64,1)$ ulaşıldı. Katılımcıların \%68,8'i (n: 53)

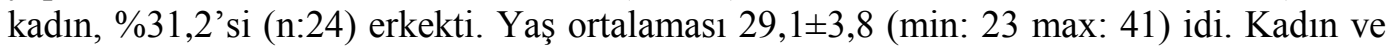
erkeklerin yaş ortalamaları birbirinden farklı değildi (p: 0,47).

Asistanların tıp fakültesinden mezuniyet yılları 1996 ve 2011 yılları arasında değişmekte olup (ortanca: 2006 yıl1), \%79,3'ü (n: 61) 2006 ve sonrası mezun olmuşlardı. Asistanlık sürelerine bakıldığında; 42 kişi $(\% 54,5) 1$ yıllık, 11 kişi $(11,3) 2$ yıllık, 24 kişi $(\% 31,2) 3$ ve üzeri yıllık asistandı. Uzmanlık sonrası planlarına bakıldığında, \%42,9'u saha hekimi, $\% 40,3$ 'ü akademisyen, \%7,8'i özel, \%1,3'ü tıp dışı bir alanda çalışmayı planlarken; $\% 7,8$ 'i ise kararsızdı. Kadın ve erkekler arasında saha hekimi veya akademisyen olarak çalışma planları arasında anlamlı fark yoktu (p: 0,25, p: 0,40). Mezuniyet yıllarına göre bakıldığında ise 2006 yılı ve sonrasında mezun olanlar daha siklıkla akademik kariyer planlamaktaydi (p: 0,01).

Katılımcıların \%68'inin (n: 53) herhangi bir sertifikası olmayıp; 17 kişinin RİA, 4 kişinin işyeri, 3 kişinin diyaliz, 2 kişinin aile hekimliği, 1 kişinin Travma ve Resüsitasyon ve 1 kişinin CPR (kardiyopulmoner resüsitasyon) sertifikası vardı.

Tıp alanındaki güncel bilgileri takip etmek için makale okuma durumları incelendiğinde, \%83,1'i (n: 64) yeterli sıklıkta makale okumadığını düşünüyordu. Türkçe makale okuma sıklıkları haftada bir $(\% 33,8)$, ayda bir $(\% 35,1)$ veya daha seyrekti $(\% 27,3)$. Ancak 
katılımcıların \%67,5'i (n: 52) sadece Türkçe yayın okumanın güncel bilgileri takip için yeterli olmadığını düşünüyordu. İngilizce makale okuma sıklıklanı ise haftada bir $(\% 19,5)$, ayda bir $(\% 10,4)$ veya daha seyrekti $(\% 50,6)$. Türkçe yayın okumanın yeterli olmadığını düşünenlerin İngilizce ve Türkçe makale okuma sıklıkları arasında istatistiksel olarak anlamlı fark bulunamadı (p: 0,10). Hiç İngilizce makale okumayanların oranı ise $\% 19,5$ (n: 15) idi.

Katılımcıların \%98,7'si (n: 76) mesleki gelişim için yabancı dilin gerekli olduğunu ifade etti. Yabancı dil bildiğini belirten 75 kişi, sıklık sırasına göre \%97,4 (n: 75) ingilizce, $\% 5,2$ almanca (n: 4) ve \%1,3 (n:1) Fransizca bilmekteydi. Yabanc1 dil düzeyi sorgulandığında; $14(\% 18,2)$ kişi yetersiz olduğunu, 35 (\%45,5) kişi okuduğunu anladığını, $15(\% 19,5)$ kişi duyduğunu anladığını ve $13(\% 16,9)$ kişi konuşabildiğini ifade etti. Katılımcıların çoğunluğu $(\% 96,1)$ yabancı dilinin geliştirilmesi gerektiğini düşünüyordu.

Aile hekimliği alanında internet kullanımı sorgulandığında, \%6,5'i (n: 5) hiç kullanmamakta; \%14,3'ü (n: 11) ayda bir, \%57,1'i (n: 44) haftada bir, \%15,6'1 (n: 12) ise hergün kullanmaktayd1. Katılımciların \%96,1'inin (n: 74) evinde interneti vard1. Kullanılan arama motorları incelendiğinde; en sık kullanılan arama motorları sirasıyla: \%83,1 Pubmed (n: 64), \%10,4 Uptodate (n: 8), \%10,4 Ulakbim (n: 8) ve \%9,1 Cochrane (n:7) idi. Bir dergide yayınlanmış veya kongrede sunulmuş, yazarları arasında oldukları en az bir makale, sözel sunum veya posteri olanların oran1 \%28,6 (n: 22) idi.

Aile hekimliği temel uygulamaları ve katılımcıların yeterlikleri kendileri tarafından değerlendirildiğinde, sağlık hizmeti verilen özel gruplar ve konulardan; ölmekte olan hasta bakımı, ergen sağlığ 1 ve danışmanlığ 1 , temel yenidoğan bakımı, madde bağımlılığı, istismar ve şiddet, çevre kaynaklı hastalıklar ve meslek hastalıkları, evde bakım, yaşam ve ölümle ilgili konularda uygulama yapma imkanlarının az olduğu görüldü. Ayrıca, gebelik öncesi bakım konusunda uygulamaları az dahi olsa katılımcılar kendilerini yeterli hissetmekteydi. Sağlık hizmeti verilen özel gruplar ve konularda katılımcıların Aile hekimliği temel uygulamaları ve yeterlikleri Tablo 1'de gösterilmiştir.

Tablo 1. Sağlık hizmeti verilen özel gruplar ve konularda katılımcıların Aile hekimliği temel uygulamaları ve yeterlikleri.

\begin{tabular}{|c|c|c|c|c|c|}
\hline \multirow{2}{*}{$\begin{array}{c}\text { Sağlık hizmeti verilen özel gruplar ve } \\
\text { konular }\end{array}$} & \multicolumn{2}{|c|}{$\begin{array}{c}\text { Uygulama durumu } \\
\mathbf{N}(\%)\end{array}$} & \multicolumn{2}{|c|}{$\begin{array}{c}\text { Yeterli hissetme } \\
\text { durumu }(\bar{X} \pm \mathrm{SS})\end{array}$} & \multirow[t]{2}{*}{$\underset{\text { değeri }}{p}$} \\
\hline & Evet & Hayır & Evet & Hayır & \\
\hline 1. Ölmekte olan hastanın bakı & $33(42,9)$ & $44(57,1)$ & $3,06 \pm 0,89$ & $1,73 \pm 1,06$ & 0,000 \\
\hline 2. Kroni & & & & & 0,000 \\
\hline 3. Aile plas & & & & & \\
\hline 4. A & & & & & \\
\hline 5. E & & & & & \\
\hline 6. C & & & & & \\
\hline 7. $\mathrm{C}$ & & & & & 0 \\
\hline 8. T & & & & & 000 \\
\hline 1 & & & & & 001 \\
\hline & & & & & 0,000 \\
\hline & & & & & 0,000 \\
\hline 12. & & & & & 0,000 \\
\hline 13. & & & & & 0,001 \\
\hline 14. Ç & 9) & 44 & 0,77 & 1,6 & 0,000 \\
\hline 15. Evde bakım & $34(44,2)$ & 43 & $3,12 \pm 1,17$ & $1,70 \pm 1,14$ & 0,000 \\
\hline 16. Ha & & 22 & $3,96 \pm 0,96$ & $1,77 \pm 1,34$ & 0,000 \\
\hline 17. $\mathrm{Y}$ & & 39 & $3,53 \pm 0,89$ & $1,74 \pm 1,14$ & 0,000 \\
\hline 18. $\mathrm{H}$ & & $35(5$ & $3,38 \pm 0,88$ & $1,46 \pm 0,88$ & 0,000 \\
\hline 19. Bilimsel makale değe & $50(64,9)$ & $27(35,1)$ & $3,14 \pm 0,94$ & $1,52 \pm 0,97$ & 0,000 \\
\hline
\end{tabular}

Aile hekimliği temel uygulamalarında sorgulanan semptomlarla ilgili klinik uygulama durumları incelendiğinde, çoğu semptom ile sıklıkla uygulama imkanlarının olduğu görüldü. Katılımcıların daha yüksek oranla uygulama imkanı bulamadıklarını ifade ettikleri semptomlar sıklık siralamasına göre; jinekomasti, galaktore, hirsutism, 
parestezi/paralizi, konvülziyon, vajinal kanamalar, kırık, davranış sorunları, idrar kaçırma ve pelvik ağrıydı. Çeşitli semptomlarla baş etme konusunda katılımcıların Aile hekimliği temel uygulamaları ve yeterlikleri Tablo 2'de gösterilmiştir.

Tablo 2. Çeşitli semptomlarla baş etme konusunda katılımcıların Aile hekimliği temel uygulamaları ve yeterlikleri.

\begin{tabular}{|c|c|c|c|c|c|}
\hline \multirow[t]{2}{*}{ Semptom } & \multicolumn{2}{|c|}{$\begin{array}{c}\text { Uygulama durumu } \\
\mathrm{N}(\%) \\
\end{array}$} & \multicolumn{2}{|c|}{$\begin{array}{l}\text { Yeterli hissetme } \\
\text { durumu }(\bar{X} \pm \mathrm{SS})\end{array}$} & \multirow[t]{2}{*}{ değeri } \\
\hline & Evet & Hayır & Evet & Hayır & \\
\hline 1. Ateş & $72(93,5)$ & $5(6,5)$ & $4,10 \pm 0,69$ & $2,00 \pm 1,41$ & 0,000 \\
\hline 2. Baș ağrıs1 & $71(92,2)$ & $6(7,8)$ & $4,07 \pm 0,78$ & $1,83 \pm 1,32$ & 0,000 \\
\hline 3. Halsizlik / Yorgunluk & $74(96,1)$ & $3(3,9)$ & $3,77 \pm 1,12$ & $2,13 \pm 1,43$ & 0,000 \\
\hline 4. İştahsızlık & $70(90,9)$ & $7(9,1)$ & $4,01 \pm 0,82$ & $1,57 \pm 1,13$ & 0,000 \\
\hline 5. Kilo kaybı (istemsiz) & $70(90,9)$ & $7(9,1)$ & $3,80 \pm 0,79$ & $1,42 \pm 1,13$ & 0,001 \\
\hline 6. Kanama diyatezi & $63(81,8)$ & $14(18,2)$ & $3,50 \pm 0,91$ & $1,64 \pm 1,00$ & 0,000 \\
\hline 7. Lenfadenopati & $69(89,6)$ & $8(10,4)$ & $3,44 \pm 0,94$ & $1,37 \pm 1,06$ & 0,000 \\
\hline 8. İkter & $66(85,7)$ & $11(14,3)$ & $3,57 \pm 0,87$ & $1,70 \pm 1,05$ & 0,000 \\
\hline 9. Ele gelen kitle & $68(88,3)$ & $9(11,7)$ & $3,63 \pm 0,86$ & $1,33 \pm 0,70$ & 0,000 \\
\hline 10. Boğaz ağrıs1 & $74(96,1)$ & $3(3,9)$ & $4,46 \pm 0,72$ & $1,00 \pm 0,00$ & 0,000 \\
\hline 11. Öksürük & $74(96,1)$ & $3(3,9)$ & $5,05 \pm 6,05$ & $1,00 \pm 0,00$ & 0,252 \\
\hline 12. Solunum sıkıntısı & $73(94,8)$ & $4(5,2)$ & $4,18 \pm 2,18$ & $1,00 \pm 0,00$ & 0,005 \\
\hline 13. Göğüs ağrıs1 & $73(94,8)$ & $4(5,2)$ & $3,92 \pm 0,89$ & $1,75 \pm 1,50$ & 0,000 \\
\hline 14. Çarpıntı & $71(92,2)$ & $6(7,8)$ & $3,77 \pm 1,00$ & $1,33 \pm 0,00$ & 0,000 \\
\hline 15. Karın ağrıs1 & $74(96,1)$ & $3(3,9)$ & $3,95 \pm 0,92$ & $1,00 \pm 0,00$ & 0,000 \\
\hline 16. Dispepsi & $74(96,1)$ & $3(3,9)$ & $4,16 \pm 0,75$ & $1,00 \pm 0,00$ & 0,000 \\
\hline 17. İshal & $74(96,1)$ & $3(3,9)$ & $4,09 \pm 0,77$ & $1,00 \pm 0,00$ & 0,000 \\
\hline 18. Kabızlık & $74(96,1)$ & $3(3,9)$ & $4,05 \pm 0,79$ & $1,00 \pm 0,00$ & 0,000 \\
\hline 19. Hematüri (kanlı idrar, kırmızı idrar) & $72(93,5)$ & $5(6,5)$ & $3,56 \pm 0,91$ & $1,40 \pm 0,89$ & 0,000 \\
\hline 20. İdrar kaçırma & $60(77,9)$ & $16(20,8)$ & $3,43 \pm 0,89$ & $1,06 \pm 0,25$ & 0,000 \\
\hline 21. Pelvik ağrı & $61(79,2)$ & $16(20,8)$ & $3,52 \pm 0,88$ & $1,19 \pm 0,40$ & 0,000 \\
\hline 22. Vaginal kanamalar & $56(72,7)$ & $21(27,3)$ & $3,48 \pm 0,93$ & $1,57 \pm 1,16$ & 0,000 \\
\hline 23. Galaktore & $52(67,5)$ & $25(32,5)$ & $3,33 \pm 0,90$ & $1,72 \pm 1,20$ & 0,000 \\
\hline 24. Hirsutism & $54(67,5)$ & $25(32,5)$ & $3,33 \pm 0,90$ & $1,72 \pm 1,20$ & 0,000 \\
\hline 25. Jinekomasti & $51(66,2)$ & $26(33,8)$ & $3,08 \pm 0,99$ & $1,65 \pm 0,97$ & 0,000 \\
\hline 26. Konvülziyon & $53(68,8)$ & $24(31,2)$ & $3,06 \pm 1,08$ & $1,63 \pm 1,01$ & 0,000 \\
\hline 27. Parestezi / paralizi & $52(67,5)$ & $25(32,5)$ & $2,90 \pm 0,93$ & $1,56 \pm 0,96$ & 0,000 \\
\hline 28. Unutkanlık & $62(80,5)$ & $15(19,5)$ & $3,23 \pm 0,94$ & $1,07 \pm 0,25$ & 0,000 \\
\hline 29. Davranış sorunları & $59(76,6)$ & $18(23,4)$ & $3,29 \pm 0,98$ & $1,39 \pm 0,91$ & 0,000 \\
\hline 30. Eklem ağrıs1 & $69(89,6)$ & $8(10,4)$ & $3,64 \pm 0,89$ & $2,00 \pm 1,19$ & 0,000 \\
\hline 31. Boyun ağrıs1 & $70(90,9)$ & $7(9,1)$ & $3,70 \pm 0,87$ & $1,86 \pm 1,21$ & 0,000 \\
\hline 32. Bel ağrıs1 & $73(94,8)$ & $4(5,2)$ & $3,75 \pm 0,87$ & $1,00 \pm 0,00$ & 0,000 \\
\hline 33. Diz ağrıs1 & $73(94,8)$ & $4(5,2)$ & $3,78 \pm 0,93$ & $1,50 \pm 1,00$ & 0,000 \\
\hline 34. Ödem & $69(89,6)$ & $8(10,4)$ & $3,61 \pm 0,86$ & $1,25 \pm 0,70$ & 0,000 \\
\hline 35. Yumuşak doku travması & $73(94,8)$ & $4(5,2)$ & $3,77 \pm 0,82$ & $1,25 \pm 0,80$ & 0,000 \\
\hline 36. Kırık & $57(74)$ & $20(26)$ & $3,32 \pm 1,07$ & $1,25 \pm 0,91$ & 0,000 \\
\hline
\end{tabular}

Katılımcılara uygulanan 'en iyi nasıl öğrenirim' anketi sonuçlarına göre, tercih ettikleri en iyi öğrenme metotları sırası ile işitsel (n: 40), kinetik (n: 28), okuyarak (n: 28) ve görseldi (n: 12). Katılımcıların çoğunluğu (\%71,4, n:55) uzaktan eğitim metodunu tercih etmiyor, \%81,8'i saha eğitiminin şart olduğunu ifade ediyordu.

\section{Tartışma}

Aile hekimliği uzmanlık eğitiminin amacı asistanın ayaktan tanı, tedavi ve takip konularında problem çözme becerilerini ve hasta bakımı konusunda yeterliğini artırmak; toplum kökenli ve kişisel bakıma alışkın, hastasını biyopsikososyal çevresiyle birlikte değerlendirebilen 5 yıldızlı hekimin özellikleri ile donanımlı uzmanlar yetiştirmektir [6].

Aile hekimliği uzmanlık eğitimi hastane rotasyonları, birinci basamak uygulama eğitimi ve eğitsel etkinliklerden oluşmaktadır. Hastane klinik rotasyonlarının amacı, Aile hekimliği uygulaması için gereken bazı becerilerin daha sık olarak uygulandığı hastane ortamlarında daha kısa sürede ve çok sayıda yapılabilmesi; kısaca eğitimde maliyet etkin çalışmanın sağlanmasıdır [2]. 
Çalışmamızda, aile hekimliği asistanlarının eğitim gereksinimi olan alanların belirlenmesi amacıyla Aile hekimliği temel uygulamaları ve yeterlikleri sorgulanmıştır. Aile Hekimliği Uzmanlık Eğitimi içerik açısından incelendiğinde sorgulanan semptomlarla ilgili uygulama imkanlarının yeterli olduğu ve kendilerini çoğunlukla yeterli hissettikleri görülmektedir. Ancak hastane rotasyonlarında uygulama imkanlarının daha seyrek olduğu; ölmekte olan hasta bakımı, ergen sağlığı ve danışmanlığı, temel yenidoğan bakımı, madde bağımlılığı, istismar ve şiddet, çevre kaynaklı hastalıklar ve meslek hastalıkları, evde bakım gibi konularda kendilerini yeterli hissetmedikleri görülmüştür. Aile hekimliği kapsamlı bir uzmanlıktır [7]. Bireyin ve ailesinin tüm sağlık sorumluluğunun üstlenilmesini gerektirir. Bu nedenle, birinci basamak uygulama eğitimi ve eğitsel etkinliklere belirtilen konuların dahil edilmesi uygun olacaktır.

Aile Hekimliği Uzmanlık Eğitimi yöntem açısından incelendiğinde, uzmanlık eğitimi esas itibariyle bir erişkin eğitimi olup [8], bu eğitimin en önemli özelliklerinden birisi eğitilen merkezli ve eğitilenin ihtiyaçlarına yönelik olmasıdır. Eğitim etkinliklerinin oluşturulmasında göz önünde bulundurulan temel prensipler arasında, eğitim amaç ve hedeflerinin önceden belirlenip açıklanması, bu amaç ve hedeflerde asistanların kişisel beklentilerini karşılayacak değişikliklerin yapılması ve karşılanamayacak beklentilerin karşılıklı görüşme ile eğitim programına konulmama gerekçelerinin tartışılmasıdır [6]. Eğitim amaçlarının ileriki profesyonel hayatları ile bağlantısının açıkça belirlenmesi ve öngörülen bilgi, beceri ve tutum hedeflerine uygun, çeşitli eğitim yöntemlerinin birlikte kullanılması, tüm eğitim etkinliklerini katılımcıların paylaşımı ile uygulama, sürekli olumlu ve iyileştirmeye yönelik eylem önerileri içeren geri bildirimlerle özgüveninin korunması erişkin eğitiminin temel ilkeleridir [9]. Uzmanlık eğitiminin tüm aşamalarında yetişkin eğitiminin temel özelliklerine uygun eğitim ortamlarının sağlanması önemlidir.

Aile Hekimliği birinci basamak sağl1k hizmetini üstlenen bir disiplin olduğu için pek çok özgün konu ancak birinci basamak uygulama ortamlarında öğrenilebilir [10]. Aile Hekimliği uzmanlık eğitiminin en az üçte birinin ve olanaklar uygun ise en az yarısının Birinci Basamak sağlık birimlerinde gerçekleştirilmesi gereği, başta EURACT (European Academy of Teachers in General Practice) olmak üzere Avrupa'daki konuyla ilgili ulusal ve uluslararası birçok örgütlenme tarafından benimsenen bir ilkedir [11]. Çalışmamızda da katılımcıların \%81,8'inin saha eğitiminin şart olduğunu ifade etmesi bunu destekleyen bir bulgudur.

Çalışmamızda katılımcıların \%54,5'inin 1. yıl asistanı olduğu görülmektedir. Bunun nedeninin, Sağlık Bakanlığının sağlıkta dönüşüm projesi kapsamında Aile hekimliği kadrolarını artırması olduğu düşünülmüştür.

Katılımcıların \%42,9'u saha hekimi, \%40,3’ü akademisyen olarak Aile Hekimliği yapmay1; özellikle de 2006 yılı ve sonrası mezun olanlar daha sıklıkla akademisyen olmayı planlamaktadır. Ancak akademisyenliğin en temel özelliklerinden biri olan güncel bilgileri takip etmek için makale okuma durumlarına bakıldığında, katılımcılar yeterli sıklıkta Türkçe ve İngilizce makale okumadıklarını belirtmektedirler. Yine aynı katılımcılar sadece Türkçe makale okumanın mesleki gelişim için yeterli olmadığını belirtmişlerdir. Yabancı dil düzeyi sorgulandığında, \%81,9'unun okuduğunu anlama ve üzeri düzeyde dil bildiğini ifade etmesine rağmen İngilizce makale okumadaki yetersizlik bir çelişki olarak dikkat çekmektedir. Elde edilen her yeni bilginin yarılanma ömrü 5 yıl gibi kısa bir süredir [12]. Uzmanlık sonrası da tıbbi bilgilerin güncel tutulması, birinci basamakta araştırma planlama ve elde edilen verilerin günlük pratiğimize yansıması açısından güncel bilgilerin takibi önemlidir.

Her insanın baskın bir öğrenme biçimi vardır [3]. Çalışmamıza göre katılımcıların en çok tercih ettikleri öğrenme metodu işitseldir. İşitsel öğrenenler için tercih edilebilecek eğitim metodları seminerler sırasında eğitime sözel katılımı teşvik etmek, konu ve vakaları tartışmak olabilir. Eğitim ve öğretim sırasında, birden çok yöntemin bir arada kullanılmasıyla öğrenmenin kalıcılığı artar [13, 14]. Baskın öğrenme biçiminin yanı sıra 
farklı öğrenme biçimleri farklı koşullarda ve gerektiğinde bir arada kullanılarak öğrenmenin kalıcılığı arttırılabilir.

Eğitsel faaliyetlerin yanı sıra, araştırma planlama ve kongre katılımları gibi bilimsel faaliyetlere katılımın teşvik edilmesi ve desteklenmesi öğrenmeye katkı sağlar. Yapılan kesitsel bir çalışmada asistan hekimlerin bilimsel faaliyetlere katılımının, yüksek iş doyumu ile ilişkili olduğu bulunmuştur $[15,16]$. Bilimsel aktiviteler zihni uyararak olumlu bir öğrenme deneyimi sağlar.

Aile Hekimliği Uzmanlık Eğitiminde her asistanın kişisel öğrenme gereksinimlerinin ortaya çıkarılması ve bu gereksinimleri nasıl karşılayacağının öğretilmesi ön planda olmalıdır. Her asistan için ayrı kişisel eğitim gereksinimi planlaması yapılmalıdır. Eğitim ve öğretim sırasında, birden çok yöntemin bir arada kullanılması öğrenmenin kalıcılığını artırır. Her bireyin farklı öğrenme metotları olduğu göz önüne alınarak, eğitim yöntemlerinin tamamının kullanılması uygun olacaktır. Aile Hekimliği Uzmanlık Eğitiminde yer alan hastane klinik rotasyonları önemli eğitim ortam ve olanaklarıdır. Ancak, diğer branşların Aile Hekimliği eğitimindeki yerlerinin ve sınırlarının belirginleştirilmesi gerekir. Bu nedenle, rotasyonlarda edinilmesi beklenen bilgi, beceri ve tutum hedefleri asistan karnesi ile belirlenmelidir.

Çalışmamızın en önemli sınılılı̆̆ 1 sadece Ankara ilindeki Aile Hekimliği asistanları ile yapılmış olmasıdır. Sonuçların ülke geneline yaygınlaştırılabilmesi için tüm ülkeyi kapsayan araştırmalar yapılmalıdır.

\section{Kaynaklar}

1. The European definition of general practice/family medicine, WONCA Europe 2002. Türkçe Çeviri ED: Başak O. Haziran 2003 (Türkiye Aile Hekimleri Uzmanlık Derneği Yayını).

2. Tekin O, Üstü Y, Uğurlu M. Aile Hekimliği Uzmanlık Eğitiminde Saha Eğitimi. Ankara Medical Journal 2012; 12: 16-21.

3. Özden Y. Öğrenme ve Öğretme. Pegem Yayıncılık. 7th ed. 2005; pp: 69.

4. Boelen $\mathrm{C}$. The five star doctor. In: changing medical education and medical practice. WHO Bulletin No 3 June 1992.

5. Fleming N, Mills C. (1992). VARK. Available at: http://www.varklearn.com/documents/The\%20VARK\%20Questionnaire\%20-\%20Turkish.pdf (Erişim tarihi: 04.02.2013)

6. Özer C, Dağdeviren N, Şahin EM, Aktürk Z. Aile Hekimliği Uzmanlık Eğitiminde Birebir Eğitim. Tıp Eğitimi Dünyası 2003; 12: 2-5.

7. Akdeniz M, Ungan M, Yaman H. Family Medicine: a Contemporary Health Care Provision System. GeroFam 2010; 1: 15-27.

8. Durak İ. Uzmanlık Eğitiminde Yeterlik Sürecinde Eğitici Gelişimi- Eğiticilerin Eğitimi. 12. Tıpta Eğitim Kurultayı 2006; pp: 63-4.

9. Wlodkowski RJ. Enhancing adult motivation to learn. Revised Edition: 69-72 Jossey-Bass Publishers. San Francisco 1999.

10. Foley EC, D'Amico F, Merenstein JH. Clinical practice arrangements of physician faculty in family practice residency programs. Fam Med 1996; 28: 6404.

11. Şensoy N, Başak O, Gemalmaz A. Umurlu Aile Hekimliği Merkezi’nde Aile Hekimliği Uygulaması ve Hasta Profili: Aile Hekimliği Alan Eğitimi Gereksinimini Ne Ölçüde Karşılıyor? Kocatepe Tıp Dergisi 2009; 10: 49-56.

12. Emanuel E. A half-life of 5 years. Can Med Assoc J 1975; 112: 572.

13. Güven $M$, Kürüm D. Öğrenme Stilleri ve Eleştirel Düşünme Arasındaki İlişkiye Genel Bir Bakış. Sosyal Bilimler Dergisi 2006; 6: 75-89.

14. Ülgen G. Eğitim Psikolojisi. Alkım Yayınevi, Ankara 1997.

15. Takahashi O, Ohde S, Jacobs JL, Tokuda Y, Omata F, Fukui T. Residents' experience of scholarly activities is associated with higher satisfaction with 
residency training. J Gen Intern Med 2009; 24: 716-20.

16. Kaya M, Üner S, Karanfil E, Uluyol R, Yüksel F, Yüksel M. The Burnout Condition of Primary Health Care Personnel. TAF Prev Med Bull 2007; 6: 357363. 